\title{
ASSESSMENT OF METALS POLLUTION IN SOME HERBS FROM KANO METROPOLIS
}

\author{
Mohammed, M.I. and Inuwa, Y. \\ Department of Pure and Industrial Chemistry Bayero University, P.M.B. 3011, Kano-Nigeria. \\ mimuhammad.chm@buk.edu.ng; dbbyusuf@gmail.com, 08065674373
}

\section{ABSTRACT}

Medicinal herbs are widely used for the prevention and treatment of various diseases, but due to the presence of toxic metals it can also present health risks, some metals at elevated levels may be toxic. The aim of this study is to determine the content, transfer factor and pollution index of cadmium, chromium, manganese and magnesium in six medicinal herbs (Leptadenia hastate, Momordica balsamina, Amaranthus viridis, Tribulus terrestris, Datura metel and Ricinus communis) and soil collected from five different areas (Bompai, Challawa, Jakara, Sharada and Watari). The samples were collected and prepared using standard analytical procedures and analytical grade reagents were used for digestion. Agilent 240FS AA model of fast sequential Atomic absorption spectroscopy was used for the analysis of the metal content of these herbs. Mg ranged from $5.30 \mathrm{mg} / \mathrm{kg}$ to $79.05 \mathrm{mg} / \mathrm{kg}$ (WHO Recommended Daily Intake $80-360 \mathrm{mgkg}$ ), Cr $0.77 \mathrm{mg} / \mathrm{kg}$ to $34.43 \mathrm{mg} / \mathrm{kg}$ (WHO Recommended Level $1.5 \mathrm{mg} \mathrm{kg}$ ), Mn $1.53 \mathrm{mg} / \mathrm{kg}$ to $20.19 \mathrm{mg} / \mathrm{kg}$ (WHO Recommended Level $200 \mathrm{mg} \mathrm{kg}$ ), Cd 0.016 to $0.89 \mathrm{mg} / \mathrm{kg}$ (WHO Recommended Level $0.3 \mathrm{mg} / \mathrm{kg}$ ). TF Bompai ranged from 0.01(Cr) to 1.25(Mg), TF Challawa ranged from $0.02(\mathrm{Mn}, \mathrm{Cr})$ to $5.28(\mathrm{Mg})$, TF Jakara ranged from $0.02(\mathrm{Cr})$ to $4.31(\mathrm{Mg})$, TF Sharada ranged from $0.02(\mathrm{Mn})$ to $4.42(\mathrm{Mg})$ and TF Watari ranged from $0.02(\mathrm{Cd}, \mathrm{Cr})$ to $5.80(\mathrm{Mg})$. Challawa sampling area exhibited highest mean PI value of 7.22 and Watari lowest with mean PI value of 2.11. The herbs analyzed contain substantial amount of $\mathrm{Cr}, \mathrm{Mn}$ and $\mathrm{Mg}$ which support the treatment of various diseases that are mainly caused due to the deficiency of those minerals. However, buildup of pollutants including heavy metals like $\mathrm{Cd}$ in the plant parts eventually enter in to human food chain. The results indicate health risk to consumers of these herbs more especially from Challawa.

Key words: Herbs, metals, Kano, Nigeria

\section{INTRODUCTION}

Medicinal herbs are sources of chemical substances that have different biological activities including those useful in the treatment of human and animal diseases (Moses et al, 2012). The ecology of a plant community is greatly influenced by physical and chemical properties of soil, particularly the presence of excess and deficiency of mineral nutrients (Bandita et al, 2011). Herbs can be toxic due to the presence of heavy metals like $\mathrm{Pb}, \mathrm{Cd}$, and other impurities, certain elements at elevated levels are also toxic; therefore quantification of various elements is important to determine the effectiveness, safety and scientific validation of therapeutic use of the plants (Ayoola and Adeyeye, 2010). Various reports have discussed the potential health implications of trace metals in medicinal herbs, since the herbal bush is known to accumulate them (Arpadjan et al, 2008 and Gomez et al, 2007). Up to $80 \%$ (WHO, 2008) or even 90\% (BBC, 2006) of some populations depend almost entirely on traditional medicine (TM) for most of their primary healthcare needs, but TMs, including herbal drugs, are hardly regulated by the State.
Ekeanyanwu et al, (2013) studied metals in nine branded Nigerian herbal products using Atomic Absorption Spectrophotometer. The contents of Copper, Manganese and Cadmium were below toxic limits in all the samples analyzed, Chromium and Nickel were not detected in the samples. They suggested need for continuous monitoring of branded herbal drugs sold in the market to ensure wholesome and safe herbal drugs. Ibrahim and Jimoh (2015) studied heavy metals ( $\mathrm{Cd}, \mathrm{Co}, \mathrm{Cr}, \mathrm{Cu}, \mathrm{Fe}, \mathrm{Mn}, \mathrm{Ni}, \mathrm{Pb}, \mathrm{Zn}$ ) and some essential macro- elements ( $\mathrm{Na}, \mathrm{K}, \mathrm{Ca}$ and $\mathrm{Mg}$ ) in twelve vegetable crops procured from Kano river basin irrigation projects site and Challlawa-Yandanko irrigation site. $\mathrm{Cd}$ in all the irrigated vegetable from Kano river exceeded permissible limits proposed by WHO/FAO and $\mathrm{EU}$, concentration of $\mathrm{Cr}$ in four vegetables from Kano river basin of $1.54 \mathrm{mg} / \mathrm{kg}$ in Horse radish leave and Cabbage, Tomato $(3.27 \mathrm{mg} / \mathrm{kg})$, and Carrot $(1.57 \mathrm{mg} / \mathrm{kg})$ exceeded WHO/FAO guidelines for safe consumption; $\mathrm{Pb}$ concentrations was above EU safe limit in Carrot $(1.0 \mathrm{mg} / \mathrm{kg})$, Garden egg $(0.67 \mathrm{mg} / \mathrm{kg})$ and Cucumber $(0.66 \mathrm{mg} / \mathrm{kg})$. 
This portrayed potential human exposure risk associated with the consumption of these vegetables.

The aim of this study was to determine the content, transfer factor and pollution index of cadmium, chromium, manganese and magnesium in six medicinal herbs collected from Bompai, Challawa, Jakara, Sharada and Watari areas of Kano State, Nigeria.

\section{MATERIALS AND METHODS}

Study areas are Bompai, Challawa, Sharada and along river Jakara, while Watari as control area Kano State, Nigeria.

Sampling Methods

Fresh samples of the plant species (Leptadenia hastate, Momordica balsamina, Amaranthus viridis, Tribulus terrestris, Datura metel and Ricinus communis) studied were collected from June to August, 2015 and were authenticated by a Botanist of the Herbarium Unit, Department of Plant Biology, Bayero University, Kano, and accession numbers were given to each sample. The plants were sampled in each location randomly and for each species, 1-2 kg of material was obtained from all locations. The plant samples were thoroughly washed with tap water and rinsed with de-ionized water to remove dust and other particles. The samples were dried at room temperature, ground sieved to fine powder and finally stored in labeled airtight cleaned plastic bottles. These samples were stored for further use.

Ashing of Plant Samples

Five gramme $(5 \mathrm{~g})$ of the ground plant samples were ashed into a constant weight in a muffle furnace at a temperature of $550^{\circ} \mathrm{C}, 20 \mathrm{~cm}^{3}$ of $0.1 \mathrm{M} \mathrm{HNO}_{3}$ analaR grade was added to the ash sample in a beaker and boiled for few minutes on a hot plate. After the appearance of white fumes, the digest (usually colorless or pink) was allowed to cool, then filtered through Nộ 1 Whatman filter paper into $100 \mathrm{~cm}^{3}$ volumetric flask and made up to the mark with $0.1 \mathrm{M} \mathrm{HNO}_{3}$. Blank was prepared using the same procedure without the sample. Both the samples and the blank were aspirated into the flame AAS for the determination of the metals. Absorbance values were recorded and the corresponding concentrations from the calibration curve plotted were determined and presented in $\mathrm{mg} / \mathrm{kg}$ dry weight (Akubugwo et al 2007; Ibrahim and Jimoh, 2015).

Digestion of Soil Samples

2 grams of each soil samples was weighed into a separate, labeled, clean, and dry $100 \mathrm{~cm}^{3}$ beaker. To each beaker $5 \mathrm{~cm}^{3}$ of water was added and then $5 \mathrm{~cm}^{3}$ concentrated $\mathrm{HNO}_{3}$, each slurry was mixed with the bare glass end of a different stirring rod and each beaker was covered with a non-ribbed watch glass, placed concave up. All the samples were heated together on one hotplate until they were refluxing (that is, until vapor is condensing on the bottom of the watch glass and dripping back down into the beaker), and were kept at reflux for 10 minutes, stirring a few times. The samples were removed from the hotplate and allowed to cool until they can be safely handled. Another $5 \mathrm{~cm}^{3}$ of concentrated $\mathrm{HNO}_{3}$ was added to each, the watch glasses were replaced, and refluxed for another 10 minutes. The samples were again allowed to cool enough to handle, then $5 \mathrm{~cm}^{3}$ of concentrated $\mathrm{HCl}$ was added and then $10 \mathrm{~cm}^{3}$ of water. The watch glass cover was replaced and refluxed for 15 minutes, stirring occasionally. Finally, each solution was filtered through No 1 filter paper into a $100 \mathrm{~cm}^{3}$ volumetric flask and was made to the mark. Blank was prepared using the same procedure without the sample. Both the samples and the blank were individually aspirated into the flame of the AAS for the determination of the metals. Absorbance values were recorded and the corresponding concentrations from the calibration curve plotted were obtained by interpolation and presented in $\mathrm{mg} / \mathrm{kg}$ dry weight (Mielke, 1999 and Yarnell, 2006).

Concentrations were determined and presented in $\mathrm{mg} / \mathrm{kg}$ using the relation in equation (1);

Element $(\mathrm{mg} / \mathrm{kg})=(\mathrm{C})(\mathrm{V})(\mathrm{d} . \mathrm{f}.) /(\mathrm{W}) \ldots$ -.-.-- (1)

where $C$ is the concentration of the element in the sample solution in $\mathrm{mg} / \mathrm{L}$; $\mathrm{V}$ is the volume of the undiluted sample solution in $\mathrm{mL} ; \mathrm{W}$ is the sample weight in grams; and d.f. is the dilution factor, if used, as described below: $d$. $f$. = (volume of diluted sample solution in $\mathrm{mL}$ )/(volume of aliquot taken for dilution in mL) (AAS manual, 1996; Edward et al, 1971).

\section{RESULTS AND DISCUSSION}

The results of the metals analyzed in the six different varieties of medicinal herbs procured from the five sampling areas were presented in table1. The analysis of variance (ANOVA) conducted to establish the differences in levels of the analyzed elements in the twelve herbs and the five sampling areas were statistically significant as $P$ values were $<0.0001$. Lowest magnesium level of $5.30 \pm 2.05 \mathrm{mg} / \mathrm{kg}$ in Devil trumpet in Watari and highest was $99.97 \mathrm{mg} / \mathrm{kg}$ in Leptadenia hastate of Jakara. The concentration of $\mathrm{Mg}$ in the soil of the five sampling areas shows the lowest magnesium value of $10.84 \pm 0.78 \mathrm{mg} / \mathrm{kg}$ in Watari control area and highest value of $74.62 \pm 0.21 \mathrm{mg} / \mathrm{kg}$ in Bompai area. 
Magnesium concentrations in this research are lower than those reported by Hassan and Umar (2006) $220 \mathrm{mg} / 100 \mathrm{~g}$ and Akubugwo et al, (2007) $(231.22 \mathrm{mg} / 100 \mathrm{~g})$ but higher than those reported by Hussain et al., (2013) $(16 \mathrm{mg} / \mathrm{kg}$ to $43 \mathrm{mg} / \mathrm{kg}$ ). Magnesium is an important mineral element in connection with circulatory diseases such as ischemic heart disease and calcium metabolism in bone (Ishida et al., 2000). In this study, high $\mathrm{Mg}$ in the leaves could be as a result of it present as component of chlorophyll (Dosunmu, 1997; Akwaowo et al., 2000). Over 300 enzymes require the presence of magnesium ions for their catalytic action, including all enzymes utilizing or synthesizing ATP, or those that use other nucleotides to synthesize DNA and RNA. Excess magnesium in the blood is freely filtered at the kidneys, and for this reason it is difficult to overdose on magnesium from dietary sources alone (Wester, 1987). The concentration of Chromium ranges from $0.77 \mathrm{mg} / \mathrm{kg}$ in Selender amaranth of Watari to $34.34 \mathrm{mg} / \mathrm{kg}$ in Devil's trumpet of Challawa. Soil $\mathrm{Cr}$ ranges from $45.89 \pm 2.09$ to $939.91 \pm 7.55 \mathrm{mg} / \mathrm{kg}$ in Watari and Challawa which was higher than $50-200 \mathrm{mg} / \mathrm{kg}$ the maximum allowable Limits (MAL) for Heavy Metals in Soil used in Different Countries (Fagbote and Olanipekun, 2010). Lower ranges of 0.5 to $30.5 \mathrm{mg} / \mathrm{kg}$ (Umoru, 2013) and 16 to $56 \mathrm{mg} / \mathrm{kg}$ (Adamu et al., 2011) were also reported. Chromium is essential in carbohydrate metabolism. It also functions in protein and cholesterol synthesis. It plays an important role in diabetes treatment as is an important element required for the maintenance of normal glucose metabolism (Ano and Ubochi, 2008). Deficiency of chromium decreases the efficiency of insulin and increases sugar and cholesterol in the blood. The toxic effects of $\mathrm{Cr}$ intake is skin rash, nose irritations, bleeds, upset stomach, kidney and liver damage, nasal itch and lungs cancer, chromium deficiency is characterized by disturbance in glucose lipids and protein metabolism (McGrath and Smith, 1990). The daily intake of $\mathrm{Cr}$ 50-200 $\mathrm{\mu g}$ has been recommended for adults by US National Academy of Sciences (Waston, 1993).

The lowest level of Manganese was $1.93 \mathrm{mg} / \mathrm{kg}$ in Leptadenia hastate of Sharada and highest was $20.19 \mathrm{mg} / \mathrm{kg}$ in Ricinus communis of Jakara. Hassan and Umar (2006) reported manganese value of $11.60 \mathrm{mg} / 100 \mathrm{~g}$, Hussain et al., (2013) reported a range of $0.26 \mathrm{mg} / \mathrm{kg}$ to $3.43 \mathrm{mg} / \mathrm{kg}$ while range of $15 \mathrm{mg} / 100 \mathrm{~g}$ to $115 \mathrm{mg} / 100 \mathrm{~g}$ in some leafy vegetables found in Cross Rivers State, Nigeria was reported by Ifon and Bassir, (1979). Soil Manganese ranges from 140.62 \pm 6.87 to $241.77 \pm 1.37 \mathrm{mg} / \mathrm{kg}$ in Watari and Jakara respectively. Lower Manganese range of 5.51 $9.61 \mu \mathrm{g} / \mathrm{g}$ was reported by Abechi et al., (2010) while higher range of 200 to $5840 \mathrm{mg} / \mathrm{kg}$ was reported by Adamu et al., (2011). It was reported that a variety of medicinal plants show great $\mathrm{Mn}$ accumulating ability (Sembratowicz et al., 2009). The RDA for manganese is 2 to $5 \mathrm{mg}$. Manganese is a cofactor for many enzymes which take part in glucose and amino acid metabolism (FAO, 2001). The result showed that the herbs are good source of manganese. Cadmium concentration ranges from $0.073 \mathrm{mg} / \mathrm{kg}$ in $R$. communis of Challawa to $0.89 \mathrm{mg} / \mathrm{kg}$ in Leptadenia hastate of Jakara, higher than the recommended level in herbs. Soil $\mathrm{Cd}$ ranges from $1.09 \pm 0.08$ to $4.09 \pm 0.09 \mathrm{mg} / \mathrm{kg}$ in Watari and Bompai which was lower than $2-8 \mathrm{mg} / \mathrm{kg}$ the maximum allowable Limits (MAL) for Heavy Metals in Soil used in Different Countries (Fagbote and Olanipekun, 2010). Higher ranges from 5.15 to $5.79 \mu \mathrm{g} / \mathrm{g}$ (Abechi et al, 2010) and $68 \mathrm{mg} / \mathrm{kg}$ (Adamu et al., 2011) were also reported. Umaru, (2013) reported a similar range of 0.1 to $4.5 \mathrm{mg} / \mathrm{kg}$. The average concentration of cadmium in Earth's crust is between 0.1 and 0.5 parts per million (ppm).

\section{Mean Soil-Herbs Transfer Factor (Tf)}

Transfer factor (TF) is used to understand the extent of risk and associated hazard due to transfer of heavy metals from the soil into the herbal plants and its subsequent accumulation, using the relation in equation (2) according to Cui et al., (2004); Anita et al.,(2010) and Ibrahim and Jimoh, (2015):

$$
\mathrm{TF}=\mathrm{Cp} / \mathrm{Cs} \text {-................. (2) }
$$

Where: $\mathrm{CP}=$ concentration of metal in the herb, $\mathrm{Cs}=$ metal concentration in the in soil sample.

This approach based on soil-plant partition coefficients can provide a simple and useful method for assessing uptake for the purposes of estimation and screening.

Among the different herbs studied, various transfer factors were generally observed, the maximum value for the transfer of the six metals to plant was obtained as: $\operatorname{TFMg}=1.23$, 5.27, 4.31, 4.47 and 5.59 at Bompai, Challawa, Jakara, Sharada and Watari sampling areas respectively, $\mathrm{TFCr}=0.03,0.08,0.23,0.14$ and 0.08 at Bompai, Challawa, Jakara, Sharada and Watari sampling areas respectively. TFMn = 0.07, 0.06, 0.09, 0.05 and 0.09 at Bompai, Challawa, Jakara, Sharada and Watari sampling areas respectively. TFCd $=0.28,0.37,0.51$, 0.15 and 0.13 at Bompai, Challawa, Jakara, Sharada and Watari sampling areas respectively. At control Area, transfer factor for all the metals was low as compared to the other sampling areas. 


\section{Special Conference Edition, November, 2017}

Table 1: Concentration of Metals in Medicinal Herbs (mg/kg dry weight) Procured from the study Areas

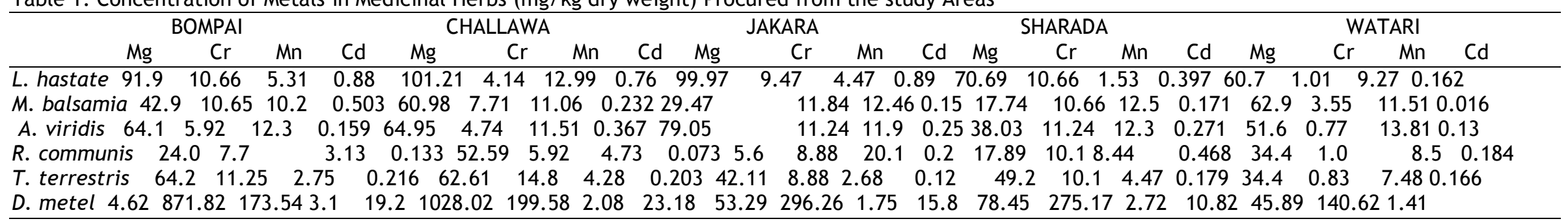

Table 2: Transfer factor of metals through different medicinal herbs at the Sampling Areas

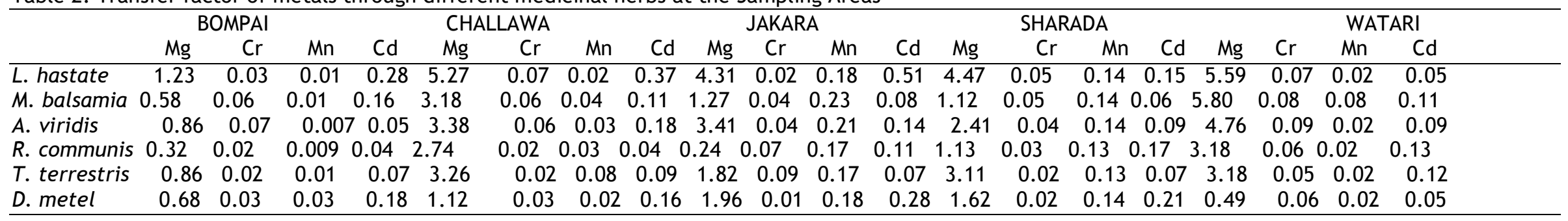

The results from this study indicated that the uptake of each metal differs from one site to another and from one plant to another and the TF for the herbs in all sites ranged differently. The reason for high TF for $\mathrm{Cd}$ might be due to its high mobility in soil (Alam et al., 2003), and the low retention of Cd (II) in the soil than other toxic cations (Lokeshwari and Chandrappa, 2006). Variations in transfer factor among different herbs may be attributed to differences in the concentration of metals in the soil and differences in element uptake by different herbs as postulated by Cui et al. (2004) and Zheng et al., (2007).

The TF value of (1) unity, indicated that the concentration of the metal in the plant was equal to that of the soil while the TF value greater than unity indicates a higher concentration of the metal in the plants than in the soil.
This indicated that plant uptake of this metal at the sites was not restricted by $\mathrm{pH}$ or other parameters (Amusan et al., 2005).

\section{Metal pollution index (MPI) of heavy metal in herbs}

Metal pollution index (MPI) was applied to examine the overall metal contents of the different herbs from the five sampling areas in order to compare and monitor the metal pollution due to aggregate effects of all the metals in the analyzed samples. Metal pollution index was computed by calculating the geometrical mean of the concentration of all the metals in the herbs using the relation according to Ghosh et al., (2013):

$$
\mathrm{MPI}=\left(\mathrm{CF} 1{ }^{*} \mathrm{CF} 2{ }^{*} \mathrm{CF} 3 . . . . . .{ }^{*} \mathrm{CFn}\right)^{1 / \mathrm{n}}
$$

Where CF1, CF2, CF3....CFn = concentrations of the studied metals 1, 2, 3 up to $\mathrm{n}$ metal in the sample. 


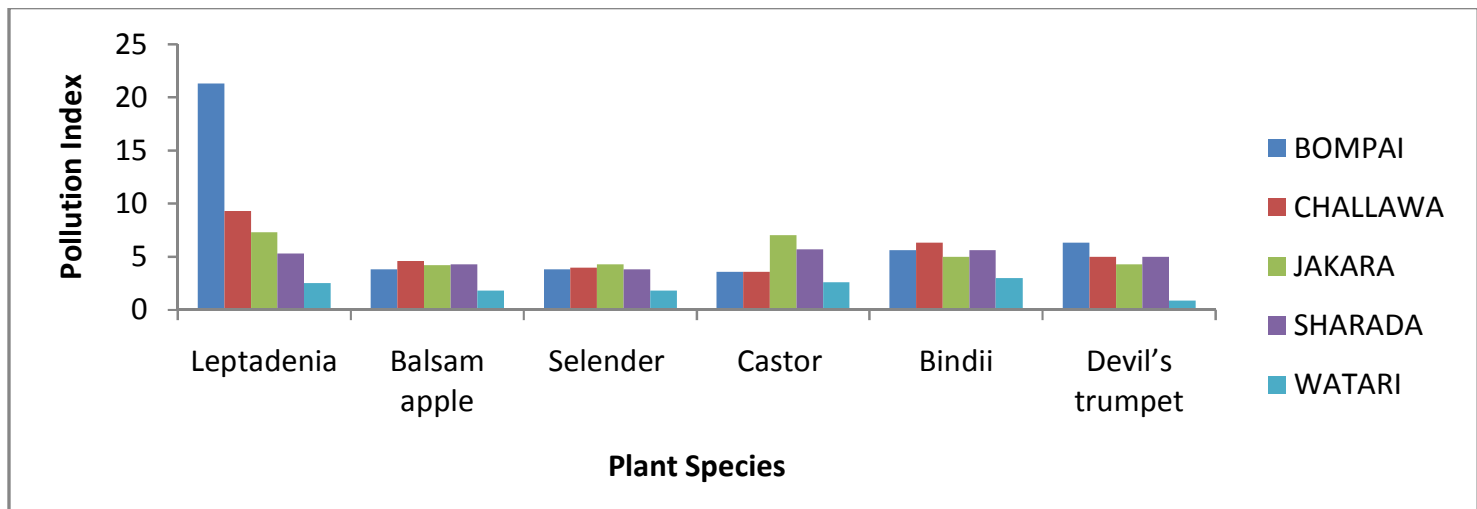

Figure 1: Metal Pollution Index of various Herbs for all Sampling Areas

Figure 1 indicates the metal Pollution Index (PI) of various herbs for the five sampling areas. At Bompai, PI ranged from 3.6 to 21.3 and from 3.6 to 9.3 at Challawa. Also PI ranges from 4.2 to $7.3,3.8$ to 5.7 and 0.9 to 2.5 at Jakara, Sharada and Watari respectively. The Mean Pollution Index for same herb from the 5 sampling areas ranged from 4.0 to 7.45 and the Mean Pollution Index for all Herbs at the same sampling area ranges from 2.11 (Watari) to 7.22 (Challawa). The Mean Pollution Index for all Herbs at the same sampling area ranges from 2.11 (Watari) to 7.22 (Challawa). Challawa sampling area exhibited highest mean PI value of 7.22 and Watari lowest with mean PI value of 2.11. The high mean pollution index obtained at Challawa indicate that herbs at this site receives loads of heavy metals which accumulated more than those from other sampling areas, hence, Challawa could be described as higher risk site compared to other areas. The mean pollution index is in order

\section{REFERENCES}

AAS Manual (1996). Analytical Method for Atomic Absorption Spectroscopy.Perkin, Elmer Inc. USA. Manual number 03030152(D). P 46-47.

Abechi, E.S.; OkunolaO.J.; Zubairu, S.M.J.; Usman A.A. and Apene E. (2010). Evaluation of heavy metals in roadside soils of major streets in Jos metropolis. Nigeria. Journal of Environmental Chemistry and Ecotoxicology. 2(6): 98102.

Adamu, C. I.; Nganje, T. N.; Ukwang, E.E.; IBE, K. A. and Peter, N. (2011). A Study of the Distribution pattern of Heavy metals in surface

soils around Arufu $\mathrm{Pb}-\mathrm{Zn}$ mine, Northeastern Nigeria, Using Factor Analysis. Research Journal of Chemical Sciences. 1 (2): 70-80 Akubugwo, I. E.; Obasi, N. A. Chinyere, G. C. and Ugbogu, A. E. (2007). Nutritional and chemical value of
Challawa > Bompai > Jakara > Sharada >> Watari.

Conclusion

The herbs analyzed contain substantial amount of $\mathrm{Cr}, \mathrm{Mn}$ and $\mathrm{Mg}$ which support the treatment of various diseases that are mainly caused due to the deficiency of those minerals. However, continuous increase in environmental pollution is leading to the buildup of pollutants including heavy metals like $\mathrm{Cd}$ in the plant parts which eventually enter in to human food chain. The variation in metals concentrations between the herbs reflects the difference in their uptake capabilities and concentration in the soil as various transfer factors were generally observed. Challawa sampling area with highest mean PI value had the highest risk and Watari been the lowest. The results indicate health risk to consumers of these herbs more especially from Challawa. The need to screen medicinal plants used in traditional medicine for their elemental composition is highly needed.

Amaranthus hybridus L.leaves from Afikpo, Nigeria. African Journal of Biotechnology, 6 (24): 2833-2839

Akwaowo, E.U.; Ndon, B.A. and Etuk, E.U. (2000). Minerals and anti-nutrients in fluted pumpkin (Telfaira occidentalis Hook F.). J. Food Chem. 70: 235- 240.

Alam, M.G.M.; Snow, E.T. and Tanaka, A. (2003). Arsenic and heavy metal contamination of vegetables grown in Samta village, Bangladesh. The Science of the Total Environment,308: 83-96.

Amusan, A.A.; Ige, D.V. and Olawale, R. (2005). Characteristics of soil and crops uptake of metal in municipal waste dumpsites in Nigeria. J.Hum. Ecol. 17: 167-171.

Anita, S.; Rajesh, K.S.; Madhoolika, A. and Fiona, M.M. (2010) Risk assessment of heavy metal toxicity through contaminated vegetables from waste water irrigated area of Varanasi, India, Tropical Ecology, (51):25: 375-387. 
Ano, A.O. and Ubochi, C.I. (2008). Nutrient composition of climbing and prostrate vegetable cowpea accessions. Africa Journal of Biotechnol, 7: 3795-3796.

Arpadjan, S.; Celik, G.; Taskesen, S. and Gücer, S. (2008). Arsenic, cadmium and lead in medicinal herbs and their fractionation. Food Chem Toxicol, 48:2871-5.

Ayoola, P.B. and Adeyeye, A.(2012). Phytochemical and nutrient evaluation of Carica papaya Pawpaw) leaves. International Journal of Res. Rev. Appl. Sci. 5: 325-328.

Bandita, D.; Gayatri, N. and Sahu, R.K. (2011). Studies on the uptake of heavy metals by selected plant species growing on coal mine spoils in sub-tropical regions of India. Journal of American Science. 7(1): 26- 34.

BBC News (2006). Can herbal medicine combat Aids? Wednesday, 15 March, 13:10 GMT.

http://newsvote.bbc.co.uk/mpapps/pagetools/pr int/news.bbc.co.uk/2/hi/Africa/4793106.stm Accessed 2011 April 16.

Cui, Y.J.; Zhu, Y.G.; Zhai R.H.; Chen D.Y.; Huang Z.H. and Qiu Y. (2004). Transfer of metals from soil to vegetables in an area near a smelter in Nanning, China. Environ. Int., 30: 785-91.

Dosunmu, M.I. (1997). Chemical composition of the fruit of Tetrapleura tetreptra and the physico-chemical Properties of its oil. Global J.Pure Appl. Sci, 3: 61-67.

Edward, J.W.; Lominol, G.D. and Buck, R.P. (1971). Determination of trace metals in high purity silver chloride by atomic absorptionspectrophotometry. Anal. Chem. Acta. (57): 257.

Fagbote E.O. and Olanipekun E.O. (2010). Evaluation of the status of Heavy Metal pollution of soil and plant (Chromolaena Odorata) of Agbadu Bitumen Deport Area, Nigeria. American- Eurasian J. Sci. Res, 5(4):241-248.

FAO (2001). Food and Agriculture Organization of the United Nations Viale delle Terme di Caracalla, 00100 Rome, Italy. Pp 1-13.

Ghosh, M. and Singh, S.P. (2005). A comparative study of cadmium phytoextraction by accumulator and weed species. Environ Pollut;133:365-71.

Gomez, R.M.; Cerutti, S.; Sombra, L.; Silva, F.M. and Martinez, D.L.(2007). Determination of heavy metals for the quality contril in argentinian herbal medicines by ETAAS and ICP-OES. Food Chem Toxicol, 45:1060-4.

Hassan, L.G. and Umar, K.J. (2006). Nutritional value of Balsam Apple (Momordica balsamina, L.) leaves. Pak. J. Nutr. 5(6): 522-529.

Hussain, J; Najeeb, R.; Abdul Latif, K.; Liaqat, A.; Ahmed, A.; Zabta, K.S.; Hidayat, H. and Tania, S.R. (2013). Proximate Based
Comparative Assessment of Five Medicinal Plants to Meet the Challenges of Malnutrition. European Journal of Medicinal Plants,3(3): 444-453.

Ibrahim, G. and Jimoh, W.L.O. (2015). Evaluation of Heavy Metal And Macro-Elements In Irrigated Vegetables From Challawa-Yandanko

And Kano River Basin Project, In Nigeria. International Journal of Scientific Research and Engineering Studies, 2(2): 35-41.

Ifon, E.T. and O. Bassir, (1979). The nutritive value of some Nigerian leafy green vegetables - Part 1:Vitamin and Mineral contents. Food Chem., 4: 263-267.

Ishida, H.; Suzuno, H.; Sugiyama, N.; Innami, S.; Todokoro, T. and Maekawa, A. (2000). Nutritional evaluation of chemical component of leaves, stalks and stems of sweet potatoes (Ipomea batatas poir). Food Chem. 68: 359-367.

Lokeshwari, H. and Chandrappa, G.T. (2006). Impact of heavy metal contamination of Bellandur Lake on soil and cultivated vegetation.Current Science, 91: 620-627.

McGrath, S.P and S.Smith, S. (1990). Chromium and Nickel in heavy metals in soils. In B.J. Alloway (ed.), Blackie, Glasgow, pp.125.

Mielke, H.(1999). Determination of lead in soil by Atomic Absorption Spectroscopy. American Scientist, 8 (1): 62-73

Moses, A.G.; Maobe, E.G.; Leonard, G. and Henry, R. (2012). Profile of Heavy Metals in Selected Medicinal Plants Used for the Treatment of Diabetes, Malaria and Pneumonia in Kisii Region, Southwest Kenya. Global Journal of Pharmacology, 6 (3): 245-251

Sembratowicz, I. ; Rusinek, E.; Ognik, K. and Truchliński, J. (2009). Concentrations of trace elements and heavy metals at selected medicinal plants harvested in two vegetation periods. kerha polonica 55(1): 22 - 28

Umoru, P.E. (2013). Assessment of Toxic Metals in Soil and Vegetable Samples from Irrigated Farmland in Kaduna Metropolis, Nigeria. International Journal of Science and Research (IJSR), 2 (2): 2319-2326.

Waston, D.(1993). Safety of chemicals in food, chemical contaminants, Published by Ellis, New York, pp109.

Wester, P.O. (1987). Magnesium. American Journal Clinical Nutrition, 45 (5): 1305-1312

WHO. (2008). Traditional Medicine. WHO Fact sheet No.134. Revised. December 2008.pp93112.

Zheng, N.; Wang, Q.C. and Zheng, D.M. (2007). Health risk of $\mathrm{Hg}, \mathrm{Pb}, \mathrm{Cd}, \mathrm{Zn}$ and $\mathrm{Cu}$ to the inhabitants around Huludao zinc plant in China via consumption of vegetables. Science of the Total Environment 383: 81-89. 